\title{
Hepatocellular Carcinoma in Oman An analysis of 284 cases
}

"Khalid Al-Naamani, ${ }^{1}$ Zamzam Al-Hashami, ${ }^{2}$ Omar Al-Siyabi, ${ }^{3}$ Mansour Al-Moundri, ${ }^{2}$ Bassim Al-Bahrani, Siham Al-Sinani, ${ }^{5}$ Ibrahim Al-Zakwani, ${ }^{6} \mathrm{Heba} \mathrm{Omar}^{7}$ Said A. Al-Busafi, ${ }^{2}$ Haifa Al-Zuhaibi, ${ }^{2}$ Abdullah AlMamari, ${ }^{8}$ Bola R. Kamath, ${ }^{1}$ Abdullah Al-Kalbani, ${ }^{1}$ Ikram Ali Burney ${ }^{2}$

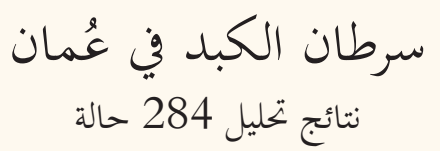

$$
\begin{aligned}
& \text { خالد النعماني، زمزم الهشامية، عمر السيابي، منصور الهنذري، باسم البحراني، سهام السنانية، إبراهيم الزكواني، هبة عمر، سعيد البوصافي، الهراني }
\end{aligned}
$$

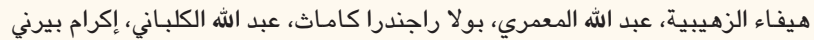

ABSTRACT: Objectives: Hepatocellular carcinoma (HCC) is the most common type of primary liver tumour worldwide and is increasing in incidence. This study aimed to describe the clinical characteristics of HCC among Omani patients, along with its major risk factors, outcomes and the role of surveillance. Methods: This retrospective case-series study was conducted between January 2008 and December 2015 at the three main tertiary care hospitals in Oman. All adult Omani patients diagnosed with HCC and visited these hospitals during the study period were included. Relevant data were collected from the patients' electronic medical records. Results: A total of 284 HCC patients were included in the analysis. The mean age was $61.02 \pm 11.41$ years and $67.6 \%$ were male. The majority had liver cirrhosis (79.9\%), with the most common aetiologies being chronic hepatitis C (46.5\%) and B (43.2\%). Only $13.7 \%$ of cases were detected by the HCC surveillance programme. Approximately half of the patients (48.5\%) had a single liver lesion and 31.9\% had a liver tumour of $>5 \mathrm{~cm}$ in size. Approximately half (49.2\%) had alpha-fetoprotein levels of $\geq 200 \mathrm{ng} / \mathrm{mL}$. The majority (72.5\%) were diagnosed using multiphase computed tomography alone. Less than half of the patients (48.9\%) were offered one or more HCC treatment modalities. Conclusion: The majority of Omani HCC patients were male and had cirrhosis due to viral hepatitis. In addition, few patients were identified by the national surveillance programme and presented with advanced disease precluding therapeutic or even palliative treatment.

Keywords: Hepatocellular Carcinoma; Liver Cirrhosis; Human Viral Hepatitis; Public Health Surveillance; Early Detection of Cancer; Alpha-Fetoprotein; Oman.

الملخص: الههف: تتزايد معدلات حدوث سرطان الكبد والذي يعد أحد أكثر أورم الكبد الأولية شيوعًا في جميع أنحاء العالم. تهدف الدراتراسة

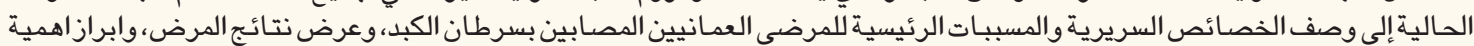

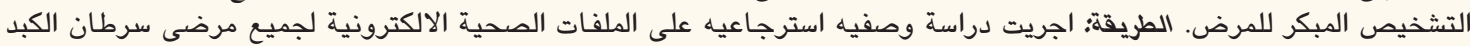

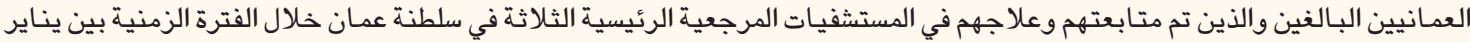

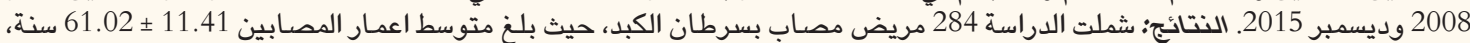

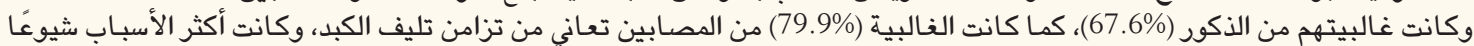

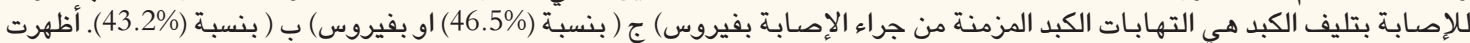

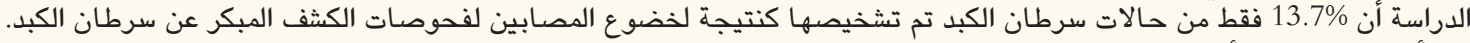



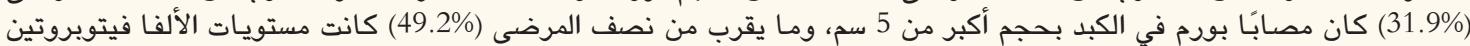

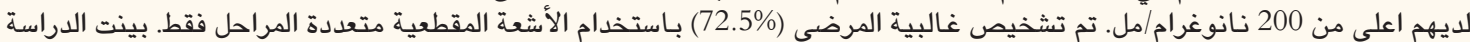

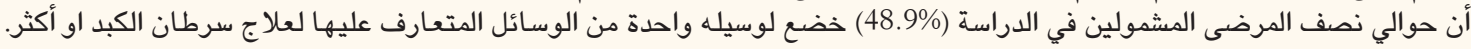

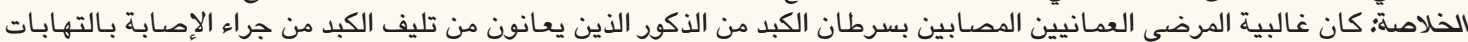

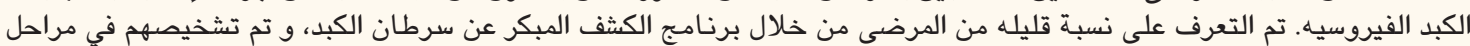

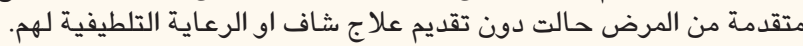

الكلمات المفتاحية؛ سرطان الكبد؛ تليف الكبد؛ التهاب الكبد الفيروسي؛ مراقبة الصحة العامة؛ الكثف المبكر عن السرطان؛ ألفا فيتوبروتين؛ عُمان.

\section{AdVANCES IN KNOWLEDGE}

This study provides clear descriptive data regarding the epidemiology of hepatocellular carcinoma (HCC) and its risk factors in Oman, along with the most frequent presentation of HCC cases and commonly used treatment modalities. 


\section{Application to Patient Care}

The findings of this study emphasise the importance of appropriate HCC screening for high-risk patients and the implementation of primary prevention strategies and early detection to reduce the rate of HCC and the negative patient outcomes associated with the disease.

$\mathrm{H}$ epatocellular CARCinoma (HCC) IS ONE of the most common cancers around the globe and represents a leading cause of cancer-related mortality. ${ }^{1}$ However, there is marked variation in the prevalence of $\mathrm{HCC}$ in different parts of the world, with more than two-thirds of cases reported from East and South Asia as well as subSaharan Africa. ${ }^{2}$ This is mainly due to differences in the prevalence of viral hepatitis, particularly hepatitis $\mathrm{B}$ and $\mathrm{C}$, the predominant causes of liver cirrhosis, a known risk factor for HCC. ${ }^{3}$ The introduction of hepatitis $\mathrm{B}$ vaccination in many countries has led to a marked reduction in HCC cases. The improvements in medical facilities with designated screening programmes similarly expected to help increase the detection rate and, therefore, improve the outcome of HCC. ${ }^{4-9}$

Despite recent marked improvements in treatment modalities, the prognosis for HCC patients remains poor, with an average five-year survival rate of approximately $\sim 5-6 \% .{ }^{10}$ Unfortunately, this is largely attributable to a lack of access to medical facilities in many underdeveloped countries. ${ }^{11}$ International guidelines recommend that HCC surveillance be performed on a six-month basis using liver ultrasonography (US), with or without measurement of alpha-fetoprotein (AFP) levels, for adults with liver cirrhosis and high-risk patients without cirrhosis such as patients with hepatitis B virus (HBV) infections. ${ }^{12,13}$ According to a meta-analysis of 47 studies, there is a significant association between HCC surveillance and detection of the tumour at an early stage, thereby increasing the likelihood of success for curative treatments such as surgical resection and liver transplantation and ultimately improving overall survival. ${ }^{14}$

In Oman, the estimated prevalence of the hepatitis $\mathrm{C}$ virus (HCV) is approximately $0.4 \%$ with genotype 1 being the most common followed by genotypes 3 and $4 .{ }^{15}$ Moreover, prior to the introduction of mass hepatitis B vaccinations in 1990, the estimated prevalence of HBV was $2-7 \% .^{16,17}$ Overall, HCC is ranked the fourth most common solid tumour among Omani male patients. ${ }^{18}$ However, there is a lack of national data evaluating the characteristics of HCC cases. As such, the primary objective of this study was to describe the clinical characteristics of HCC cases in Oman, with the secondary objectives being to determine the major risk factors, role of surveillance and outcomes of HCC among Omani patients.

\section{Methods}

This retrospective case-series study was conducted from January 2008 to December 2015 at the Sultan Qaboos University Hospital, Armed Forces Hospital and The Royal Hospital. All adult Omani patients with one or more hepatic lesions who have been diagnosed with HCC were included in the study. NonOmani patients and those with benign liver lesions, liver metastasis from a primary distant tumour, cholangiocarcinomas or hepatoblastomas were excluded, as were patients for whom there was no data concerning the number and size of HCC lesion(s). The sample was considered to be nationally representative as these three hospitals are the main tertiary hospitals in the capital city of Muscat and are the centres to which all $\mathrm{HCC}$ cases are referred to from other regions of Oman.

Relevant data were collected from the electronic medical records at each hospital including information regarding the patients' sociodemographic characteristics, laboratory findings, tumour aetiology, characteristics and radiological features at the time of presentation as well as the treatment modalities offered. In all cases, the diagnosis of HCC was based on the criteria of the American Association for the Study of Liver Disease in terms of typical enhancement patterns upon radiological examination or histopathological analysis. ${ }^{13,19}$ Moreover, the severity of liver cirrhosis cases was classified using the Child-Pugh scoring system as either class A (scores of 5-6), class B (scores of 7-9) or class C (scores of 10-15). ${ }^{20}$

Detailed information concerning each patient was available from the electronic medical record systems of each of the three participating hospitals along with the findings of any laboratory and radiological investigations conducted both at first presentation and during subsequent visits. Patients were either seen initially at one of the three tertiary hospitals or were referred immediately after the initial diagnosis of HCC. Laboratory and radiological investigations were repeated for all referred patients at presentation to each of the three tertiary hospitals.

In addition, $\mathrm{HCC}$ cases were assessed according to the Milan criteria regarding their suitability for 
Table 1: Sociodemographic and clinical characteristics of Omani patients with hepatocellular carcinoma $(\mathrm{N}=284)$

$\begin{array}{lc}\text { Characteristic } & \mathbf{n}(\%) \\ \text { Mean age in years } \pm \text { SD } & 61.02 \pm 11.41 \\ \text { Gender } & \\ \text { Male } & 192(67.6) \\ \text { Female } & 92(32.4) \\ \text { Presence of liver cirrhosis } & \\ \text { Yes } & 227(79.9) \\ \text { No } & 57(20.1) \\ \text { Class of liver cirrhosis* } & \\ \text { Class A } & 76(34.1) \\ \text { Class B } & 82(36.8) \\ \text { Class C } & 65(29.2) \\ \text { Aetiology of liver cirrhosis } & \\ \text { HCV } & \\ \text { HBV } & 99(46.5) \\ \text { Alcoholic liver disease } & 92(43.2) \\ \text { Cryptogenic } & 20(9.4) \\ \text { SD = standard deviation; HCV = hepatitis C virus; } & \text { HBV = hepatitis B } \\ \text { virus. } & \\ \text { *According to the Child-Pugh scoring system.19 } & \text { Total dataset for this vari- } \\ \text { able was } 223 \text { as four patients were excluded due to missing data. }{ }^{+} \text {Total } \\ \text { in 10 cases. }\end{array}$

liver transplantation..$^{21}$ Based on overall and diseasefree survival rates, these guidelines state that only patients with one lesion of $<5 \mathrm{~cm}$ in size or up to three lesions of $<3 \mathrm{~cm}$ each and with no evidence of extrahepatic disease or vascular invasion are eligible for transplantation. ${ }^{21}$ Performance status was assessed using the Eastern Clinical Oncology Group (ECOG) scale as follows: grade zero (fully active and able to continue all pre-disease activities without restriction); grade 1 (restricted in physically strenuous activities but ambulatory and able to carry out work of a light or sedentary nature); grade 2 (ambulatory, out of bed for $>50 \%$ of waking hours and capable of unrestricted self-care, but unable to carry out any work activities); grade 3 (capable of limited self-care and confined to a bed or chair for $>50 \%$ of waking hours); or grade 4 (completely disabled, unable to perfom any self-care and totally confined to a bed or chair). ${ }^{22}$

The statistical analyses were conducted using Stata ${ }^{\circledR}$ data analysis and statistical software, Version 14.2 (StataCorp LLC, College Station, Texas, USA). Categorical variables were reported using frequencies and percentages, while continuous variables were presented using means and standard deviations.
Table 2: Tumour characteristics of Omani patients with hepatocellular carcinoma $(\mathrm{N}=284)$

\begin{tabular}{|c|c|}
\hline Characteristic & n (\%) \\
\hline \multicolumn{2}{|c|}{ Number of lesions* } \\
\hline 1 & $127(48.5)$ \\
\hline $2-3$ & $34(13)$ \\
\hline$>3$ & $65(24.8)$ \\
\hline Diffuse lesions & $36(13.7)$ \\
\hline \multicolumn{2}{|c|}{ Size of lesions in $\mathrm{cm}^{+}$} \\
\hline$<2$ & $36(13.7)$ \\
\hline $2-5$ & $101(38.4)$ \\
\hline$>5$ & $84(31.9)$ \\
\hline Diffuse lesions & $42(16)$ \\
\hline \multicolumn{2}{|c|}{ AFP level in $\mathrm{ng} / \mathrm{mL}^{\ddagger}$} \\
\hline$<200$ & $123(50.8)$ \\
\hline $200-400$ & $13(5.4)$ \\
\hline$>400$ & $106(43.8)$ \\
\hline \multicolumn{2}{|c|}{ Eligibility for transplantation $\$$} \\
\hline Eligible & $65(22.9)$ \\
\hline
\end{tabular}

The association between AFP levels and status of transplantation eligibility according to the Milan criteria was examined using a Pearson's Chi-squared test. The a priori two-tailed level of significance was set at $P<0.050$.

This study was approved by the individual institutional research and ethics committees of the Sultan Qaboos University Hospital, Armed Forces Hospital and The Royal Hospital.

\section{Results}

A total of $284 \mathrm{HCC}$ patients were included in the final analysis. The mean age was $61.02 \pm 11.41$ years (range: 24-84 years) and $67.6 \%$ were male. Overall, 227 patients $(79.9 \%)$ had liver cirrhosis, most frequently classified as Child-Pugh class B (36.8\%) followed by class A (34.1\%) and class C (29.2\%). The underlying aetiology of the liver cirrhosis could be determined in 213 patients (75\%); of these cases, the majority were caused by $\mathrm{HCV}$ (46.5\%) or HBV (43.2\%) infections [Table 1].

Only 39 patients (13.7\%) were identified via the surveillance programme using AFP and liver US every 
Table 3: Association between alpha-fetoprotein levels and eligibility for transplantation among Omani patients with hepatocellular carcinoma $(\mathrm{N}=284)^{* *}$

\begin{tabular}{|c|c|c|c|}
\hline \multirow[t]{2}{*}{$\begin{array}{l}\text { Eligibility for } \\
\text { transplantation }\end{array}$} & \multicolumn{2}{|c|}{$\begin{array}{l}\text { AFP category, } \\
\text { n (\%) }\end{array}$} & \multirow[t]{2}{*}{$P$ value } \\
\hline & $\begin{array}{c}\text { Low } \\
(n=131)\end{array}$ & $\begin{array}{c}\text { High } \\
(\mathbf{n}=102)\end{array}$ & \\
\hline Eligible & 48 (36.6) & 17 (16.7) & \multirow{2}{*}{0.001} \\
\hline Ineligible & $83(63.4)$ & 85 (83.3) & \\
\hline
\end{tabular}

six months. To confirm the diagnosis, the majority of patients (72.5\%) required one modality of imaging (multiphase computed tomography [CT] of the liver), with the remaining patients $(27.5 \%)$ requiring two modalities (both multiphase $\mathrm{CT}$ and contrastenhanced magnetic resonance imaging [MRI] of the liver). Just under half of the patients (48.5\%) had a single focal lesion. In $38.4 \%$ of patients, the focal lesions ranged in diameter from $2-5 \mathrm{~cm}$. Approximately half of the cohort (50.8\%) had AFP levels of $<200 \mathrm{ng} / \mathrm{mL}$, while only $21.8 \%$ were considered suitable for liver transplantation as per the Milan criteria [Table 2].

There was a significant association between AFP levels and transplantation eligibility according to the Milan criteria, with $36.6 \%$ and $16.7 \%$ of patients with AFP levels of $\leq 400$ and $>400 \mathrm{ng} / \mathrm{mL}$, respectively, considered suitable for liver transplantation ( $P$ $<0.001$ ) [Table 3]. Overall, $48.9 \%$ were offered one of more modalities of treatment including tumour resection, radiofrequency ablation (RFA), transarterial chemoembolisation, kinase inhibitor drug therapy (in the form of sorafenib) and liver transplantation. However, the remaining $51.1 \%$ of patients were beyond curative treatment due to advanced disease stage, the presence of comorbidities and/or poor performance status (i.e. ECOG scores of $>2$ ) at presentation [Table 4].

\section{Discussion}

The Oman National Cancer Registry was first established in 1985 as a hospital-based endeavour, before being incorporated under the umbrella of the Department of Non-Communicable Diseases Surveillance and Control of the Ministry of Health in 1996. Subsequently, the notification and record of all cancer cases in the country was made mandatory in 2001. ${ }^{23}$ Despite governmental efforts, some cancer cases are still not registered in Oman for a variety of reasons, including the fact that a considerable number of patients choose to seek diagnosis and
Table 4: Treatment modalities offered to Omani patients with hepatocellular carcinoma $(\mathrm{N}=284)$

$\begin{array}{lc}\text { Modality } & \mathbf{n}(\%) \\ \text { None } & 145(51.1) \\ \text { Resection alone } & 14(4.9) \\ \text { Resection plus RFA } & 2(0.7) \\ \text { Resection plus TACE } & 1(0.4) \\ \text { Resection plus transplantation } & 2(0.7) \\ \text { Resection plus sorafenib } & 2(0.7) \\ \text { RFA alone } & 16(5.6) \\ \text { RFA plus TACE } & 5(1.8) \\ \text { RFA, TACE and sorafenib } & 2(0.7) \\ \text { RFA plus sorafenib } & 3(1.1) \\ \text { TACE alone } & 31(10.9) \\ \text { TACE plus sorafenib } & 20(7) \\ \text { TACE plus transplantation } & 1(0.4) \\ \text { Resection, TACE and sorafenib } & 2(0.7) \\ \text { Resection, RFA, TACE and sorafenib } & 1(0.4) \\ \text { Transplantation alone } & 2(0.7) \\ \text { Sorafenib alone } & 33(11.6) \\ \text { Transplantation plus sorafenib } & 2(0.7) \\ \text { RFA radiofrequencyablation; TACE = transarterial chemoembolisation. }\end{array}$

medical treatment abroad. To the best of the authors' knowledge, this study is the first of its kind to analyse the characteristics and risk factors of Omani patients with HCC.

In the current study, the majority of Omani HCC patients were older males. Research has shown that $\mathrm{HCC}$ is much more common in men, possibly due to behaviours linked to known HCC risk factors such as alcohol consumption and smoking. ${ }^{24}$ Moreover, epidemiological studies from other parts of the world have shown that the incidence of HCC increases with age, although the age of peak incidence varies; for example, HCC incidence increases progressively until 70 years of age in Taiwan, whereas it reportedly peaks at 55 years in Africa. ${ }^{25,26}$ High incidence rates in older patients could be attributed to longer durations of viral hepatitis infections leading to advanced fibrosis and cirrhosis. However, the effect of age per se cannot be excluded, since other solid organ tumours also occur at a higher rate in older patients. ${ }^{27}$ McMahon et al. reported that an annual HCC incidence of $0.26 \%$ in $<20$-year-old males with HBV, which increased to $1.1 \%$ for those aged $>50$ years. ${ }^{4}$

The most prevalent risk factor for HCC in the present study was cirrhosis affecting $79.9 \%$ of cases. 
Cirrhosis is a well-known risk factor for HCC; the annual risk of developing HCC is $1-6 \%$ for cirrhotic patients with up to $60-80 \%$ of HCC patients having underlying cirrhosis. ${ }^{28,29}$ This wide range in reported incidence reflects differences in the population being studied, for instance in terms of age, gender, aetiology and duration of cirrhosis. ${ }^{29}$ Ethnicity has also been noted to play a role in the incidence of HCC..$^{30,31}$ The high incidence of $\mathrm{HCC}$ in young African patients is most likely secondary to multiple additive factors, such as genetic background, HBV infection and exposure to aflatoxins..$^{24,32}$ In the current study, HCV was the most common cause of cirrhosis followed by HBV. This is unsurpising, given the dramatic reduction in the seroprevalence of chronic HBV infections in Oman following the successful introduction of HBV vaccination in $1990 .{ }^{17}$ Similar findings have also been reported in Saudi Arabia. ${ }^{33}$

Various decision analysis models have demonstrated the cost-effectiveness of HCC surveillance. ${ }^{34,35}$ According to these models, twice yearly surveillance is indicated if the incidence of $\mathrm{HCC}$ is $\geq 1.5 \%$ per year. ${ }^{34,35}$ Based on international guidelines and recorded tumour doubling time, the HCC surveillance programme in Oman involves biannual liver US and serum AFP level evaluations. ${ }^{12,13}$ Unfortunately, only $13.7 \%$ of patients in the present cohort were detected as a result of this programme. This can be attributed to the asymptomatic nature of most liver diseases or the fact that many individuals choose not to seek routine medical attention until later in life. Moreover, many Omani patients may lack awareness of the complications of viral hepatitis and the importance of surveillance in the early detection and treatment of HCC. Furthermore, patients with HBV infections may have been considered to have chronic inactive hepatitis and thus were not included within the surveillance programme.

In a meta-analysis of 19 studies, Singal et al. observed that twice yearly surveillance using liver US increased the sensitivity for detecting early-stage HCC to $70 \%{ }^{36}$ Similarly, Santi et al. demonstrated a higher detection rate of early-stage HCC cases with biannual rather than annual surveillance, leading to a high cure rate and better prognosis. ${ }^{37}$ However, decreasing the surveillance interval from six to three months was not found to result in any additional benefit to survival. ${ }^{38}$ A systematic review of nine studies showed that HCC surveillance rates were significantly higher among patients seen by gastroenterology subspecialists compared to those attended by primary care physicians (51.7\% versus $16.9 \%$; $P<0.001) .{ }^{39}$ Increasing awareness of liver diseases among medical staff, screening high- risk patients, encouraging early referral of suspected cases and actively counseling patients and their families are recommended measures to enhance the effectiveness of the national HCC surveillance programme in Oman.

Previous research has provided evidence regarding the limited usefulness of AFP as a screening modality for HCC..$^{34,35,40}$ Indeed, $50.8 \%$ of HCC patients in the present study had AFP levels of $<200$ $\mathrm{ng} / \mathrm{mL}$. According to Trevisani et al., an AFP cutoff value of $20 \mathrm{ng} / \mathrm{mL}$ provides the optimal balance between sensitivity and specificity; however, at this level, the sensitivity is low. ${ }^{41}$ Elevated AFP levels have been described in non-HCC liver lesions such as intrahepatic cholangiocarcinomas and in cases of liver metastasis from the colon and stomach. ${ }^{42-44} \mathrm{An}$ interesting observation in the present study was the significant association between high AFP levels $(>400$ $\mathrm{ng} / \mathrm{mL}$ ) and ineligibility for liver transplantation as per the Milan criteria. ${ }^{21}$ This confirms findings reported by Tangkijvanich et al. in which the researchers described an association between high serum AFP levels and large tumour size, bilobar involvement, massive or diffuse-type tumours and portal vein tumour thrombus. ${ }^{45}$ This is worth investigating further in larger-scale prospective studies.

Abdominal US was the most frequently employed modality for HCC screening in the current study. However, the diagnosis of HCC was based on multiphase liver $\mathrm{CT}$ in the majority of patients (72.5\%). Generally, US has been reported to have a sensitivity of $65-80 \%$ and a specificity of $>90 \%$ when used as a screening test. ${ }^{46}$ However, the accuracy of this modality is operator-dependent as a small HCC lesion may be missed against the background of a multinodular liver. In addition, US has lower sensitivity for the detection of early-stage HCC in obese patients and patients with fatty livers. ${ }^{13,47}$ As such, abdominal US should be followed by multiphase CT of the liver or contrast-enhanced MRI in order to identify small or early-stage and small HCCs. ${ }^{13,48}$ However, only a minority of the patients in the present study required more than one modality for the diagnosis of HCC due to atypical radiological patterns.

Unfortunately, less than half of the patients in the present study were offered treatment. Among those who were, various modalities were employed, either alone or in combination, to treat patients with different stages of HCC. Few patients received curative treatment in the form of liver resection, RFA or liver transplantation. In many cases, treatment was limited due to high Child-Pugh scores-with approximately two-thirds of the patients categorised as class B or C- 
poor performance status (ECOG scores of $>2$ ) and/ or advanced stages of disease based on the Barcelona Clinic Liver Cancer staging system. ${ }^{49}$

This study was limited by certain factors. Due to its retrospective nature, some data were missing for certain variables. Moreover, several patients presented in an advanced stage of disease with comorbidities such as renal failure which precluded the use of radiological investigations such as multiphase CT or contrastenhanced MRI for definitive diagnosis and staging. Another major limitation was the inability to report the true incidence and trend of HCC cases in Oman due to the fact that some patients were diagnosed and treated outside of the country.

\section{Conclusion}

This study represents the first of its kind to describe the clinical characteristics and risk factors of HCC in Oman. The majority of patients were male and had liver cirrhosis caused by viral hepatitis. In addition, approximately two-thirds presented with advanced disease (Child-Pugh classes B or C). There is an urgent need to enhance the existing HCC surveillance programme in order to encourage early detection of $\mathrm{HCC}$ and increase the likelihood of curative treatment.

\section{CONFLICT OF INTEREST}

The authors declare no conflicts of interest.

\section{FUNDING}

No funding was received for this study.

\section{AUTHOR CONTRIBUTIONS}

All authors participated in this research. KN contributed to the draft conception, concept design and writing of the manuscript, while $\mathrm{ZH}$ and SS contributed to the concept design and writing of the manuscript. IZ and $\mathrm{HO}$ contributed to the data analysis. All other authors contributed equally to the writing of the manuscript including $\mathrm{MM}, \mathrm{BB}, \mathrm{OS}$, SAB, AM, HZ, BRK, AK and IAB.

\section{References}

1. Jemal A, Bray F, Center MM, Ferlay J, Ward E, Forman D. Global cancer statistics. CA Cancer J Clin 2011; 61:69-90. https://doi. org/10.3322/caac.20107.

2. Choo SP, Tan WL, Goh BK, Tai WM, Zhu AX. Comparison of hepatocellular carcinoma in Eastern versus Western populations. Cancer 2016; 122:3430-46. https://doi.org/10.1002/cncr.3 0237.

3. Dhanasekaran R, Limaye A, Cabrera R. Hepatocellular carcinoma: Current trends in worldwide epidemiology, risk factors, diagnosis, and therapeutics. Hepat Med 2012; 4:19-37. https://doi.org/10.2147/HMER.S16316.
4. McMahon BJ, Alberts SR, Wainwright RB, Bulkow L, Lanier AP. Hepatitis B-related sequelae: Prospective study in 1400 hepatitis B surface antigen-positive Alaska native carriers. Arch Intern Med 1990; 150:1051-4. https://doi.org/10.1001/ archinte.150.5.1051.

5. Sherman M, Peltekian KM, Lee C. Screening for hepatocellular carcinoma in chronic carriers of hepatitis B virus: Incidence and prevalence of hepatocellular carcinoma in a North American urban population. Hepatology 1995; 22:432-8. https://doi. org/10.1002/hep.1840220210.

6. Fattovich G, Giustina G, Schalm SW, Hadziyannis S, SanchezTapias J, Almasio P, et al. Occurrence of hepatocellular carcinoma and decompensation in western European patients with cirrhosis type B: The EUROHEP Study Group on Hepatitis B Virus and Cirrhosis. Hepatology 1995; 21:77-82. https://doi. org/10.1002/hep.1840210114.

7. Fattovich G, Giustina G, Degos F, Tremolada F, Diodati G, Almasio P, et al. Morbidity and mortality in compensated cirrhosis type C: A retrospective follow-up study of 384 patients. Gastroenterology 1997; 112:463-72. https://doi. org/10.1053/gast.1997.v112.pm9024300.

8. Bruix J, Barrera JM, Calvet X, Ercilla G, Costa J, SanchezTapias JM, et al. Prevalence of antibodies to hepatitis $C$ virus in Spanish patients with hepatocellular carcinoma and hepatic cirrhosis. Lancet 1989; 2:1004-6. https://doi.org/10.1016/ s0140-6736(89)91015-5.

9. Niederau C, Lange S, Heintges T, Erhardt A, Buschkamp M, Hürter D, et al. Prognosis of chronic hepatitis C: Results of a large, prospective cohort study. Hepatology 1998; 28:1687-95. https://doi.org/10.1002/hep.510280632

10. Buonaguro L, Petrizzo A, Tagliamonte M, Tornesello ML, Buonaguro FM. Challenges in cancer vaccine development for hepatocellular carcinoma. J Hepatol 2013; 59:897-903. https:// doi.org/10.1016/j.jhep.2013.05.031.

11. Ladep NG, Lesi OA, Mark P, Lemoine M, Onyekwere C, Afihene M, et al. Problem of hepatocellular carcinoma in West Africa. World J Hepatol 2014; 6:783-92. https://doi.org/10.4254/wjh. v6.i11.783

12. Omata M, Cheng AL, Kokudo N, Kudo M, Lee JM, Jia J, et al. Asia-Pacific clinical practice guidelines on the management of hepatocellular carcinoma: A 2017 update. Hepatol Int 2017; 11:317-70. https://doi.org/10.1007/s12072-017-9799-9.

13. Marrero JA, Kulik LM, Sirlin CB, Zhu AX, Finn RS, Abecassis MM, et al. Diagnosis, staging, and management of hepatocellular carcinoma: 2018 practice guidance by the American Association for the Study of Liver Diseases. Hepatology 2018; 68:723-50. https://doi.org/10.1002/hep.29913.

14. Singal AG, Pillai A, Tiro J. Early detection, curative treatment, and survival rates for hepatocellular carcinoma surveillance in patients with cirrhosis: A meta-analysis. PLoS Med 2014; 11:e1001624. https://doi.org/10.1371/journal.pmed.1001624.

15. Blach S, Zeuzem S, Manns M, Altraif I, Duberg AS, Muljono DH, et al. Global prevalence and genotype distribution of hepatitis $C$ virus infection in 2015: A modelling study. Lancet Gastroenterol Hepatol 2017; 2:161-76. https://doi.org/10.1016/s2468-1253(16) 30181-9.

16. Al-Naamani K, Al-Maqbali A, Al-Sinani S. Characteristic of hepatitis B infection in a sample of Omani patients. Sultan Qaboos Univ Med J 2013; 13:380-5. https://doi. org/10.12816/0003259.

17. Al Awaidy ST, Bawikar SP, Al Busaidy SS, Al Mahrouqi S, Al Baqlani S, Al Obaidani I, et al. Progress toward elimination of hepatitis B virus transmission in Oman: Impact of hepatitis B vaccination. Am J Trop Med Hyg 2013; 89:811-15. https://doi. org/10.4269/ajtmh.13-0333.

18. Al-Lawati JA, Santhosh-Kumar CR, Mohammed AJ, Jaffer MA. Cancer incidence in Oman, 1993-1997. East Mediterr Health J 1999; 5:1035-41. 
19. Bruix J, Sherman M; American Association for the Study of Liver Diseases. Management of hepatocellular carcinoma: An update. Hepatology 2011; 53:1020-2. https://doi.org/10.1002/ hep. 24199.

20. Pasqualetti P, Di Lauro G, Festuccia V, Giandomenico G, Casale R. Prognostic value of Pugh's modification of Child-Turcotte classification in patients with cirrhosis of the liver. Panminerva Med 1992; 34:65-8.

21. Mazzaferro V, Regalia E, Doci R, Andreola S, Pulvirenti A, Bozzetti F, et al. Liver transplantation for the treatment of small hepatocellular carcinomas in patients with cirrhosis. N Engl J Med 1996; 334:693-9. https://doi.org/10.1056/ NEJM199603143341104.

22. Oken MM, Creech RH, Tormey DC, Horton J, Davis TE, McFadden ET, et al. Toxicity and response criteria of the Eastern Cooperative Oncology Group. Am J Clin Oncol 1982; 5:649-55. https://doi.org/10.1097/00000421-198212000-00014.

23. Nooyi SC, Al-Lawati JA. Cancer incidence in Oman, 19982006. Asian Pac J Cancer Prev 2011; 12:1735-8.

24. Barazani Y, Hiatt JR, Tong MJ, Busuttil RW. Chronic viral hepatitis and hepatocellular carcinoma. World J Surg 2007; 31:1243-8. https://doi.org/10.1007/s00268-007-9041-3.

25. Beasley RP, Hwang LY, Lin CC, Chien CS. Hepatocellular carcinoma and hepatitis B virus: A prospective study of 22 707 men in Taiwan. Lancet 1981; 2:1129-33. https://doi. org/10.1016/s0140-6736(81)90585-7.

26. Parkin DM, Bray F, Ferlay J, Pisani P. Global cancer statistics, 2002. CA Cancer J Clin 2005; 55:74-108. https://doi. org $/ 10.3322 /$ canjclin.55.2.74.

27. William B. Ershler, Dan L. Longo, Aging and Cancer: Issues of Basic and Clinical Science, J Natl Cancer Inst 1997; 89:1489-97. https://doi.org/10.1093/jnci/89.20.1489.

28. McGlynn KA, London WT. Epidemiology and natural history of hepatocellular carcinoma. Best Pract Res Clin Gastroenterol 2005; 19:3-23. https://doi.org/10.1016/j.bpg.2004.10.004.

29. Chiesa R, Donato F, Tagger A, Favret M, Ribero ML, Nardi G, et al. Etiology of hepatocellular carcinoma in Italian patients with and without cirrhosis. Cancer Epidemiol Biomarkers Prev 2000; 9:213-16.

30. Nguyen MH, Whittemore AS, Garcia RT, Tawfeek SA, Ning J, Lam S, et al. Role of ethnicity in risk for hepatocellular carcinoma in patients with chronic hepatitis $\mathrm{C}$ and cirrhosis. Clin Gastroenterol Hepatol 2004; 2:820-4. https://doi.org/10.1016/ s1542-3565(04)00353-2.

31. El-Serag HB. Epidemiology of hepatocellular carcinoma in USA. Hepatol Res 2007; 37:S88-94. https://doi.org/10.1111/ j.1872-034X.2007.00168.x.

32. Liu Y, Wu F. Global burden of aflatoxin-induced hepatocellular carcinoma: A risk assessment. Environ Health Perspect 2010; 118:818-24. https://doi.org/10.1289/ehp.0901388.

33. Alkhayyat S, Fallatah HI, Akbar HO, Al Ahwal, MS, Al Ghamdi WS. Causes and stages of hepatocellular carcinoma at patient presentation at a tertiary medical center in Western Saudi Arabia. J Cancer Ther 2014; 5:1303-10. https://doi.org/10.4236/ jct.2014.514130.

34. Sarasin FP, Giostra E, Hadengue A. Cost-effectiveness of screening for detection of small hepatocellular carcinoma in Western patients with Child-Pugh class A cirrhosis. Am J Med 1996; 101:422-34. https://doi.org/10.1016/S0002-9343(96)00197-0.
35. Arguedas MR, Chen VK, Eloubeidi MA, Fallon MB. Screening for hepatocellular carcinoma in patients with hepatitis C cirrhosis: A cost-utility analysis. Am J Gastroenterol 2003; 98:679-90. https://doi.org/10.1111/j.1572-0241.2003.07327.x.

36. Singal A, Volk ML, Waljee A, Salgia R, Higgins P, Rogers MA, et al. Meta-analysis: Surveillance with ultrasound for early-stage hepatocellular carcinoma in patients with cirrhosis. Aliment Pharmacol Ther 2009; 30:37-47. https://doi.org/10.1111/j.13652036.2009.04014.x.

37. Santi V, Trevisani F, Gramenzi A, Grignaschi A, Mirici-Cappa F, Del Poggio P, et al. Semiannual surveillance is superior to annual surveillance for the detection of early hepatocellular carcinoma and patient survival. J Hepatol 2010; 53:291-7. https://doi. org/10.1016/j.jhep.2010.03.010.

38. Trinchet JC, Chaffaut C, Bourcier V, Degos F, Henrion J, Fontaine H, et al. Ultrasonographic surveillance of hepatocellular carcinoma in cirrhosis: a randomized trial comparing 3- and 6-month periodicities. Hepatology 2011; 54:1987-97. https://doi.org/10.1002/ hep. 24545 .

39. Singal AG, Yopp A, Skinner CS, Packer M, Lee WM, Tiro JA. Utilization of hepatocellular carcinoma surveillance among American patients: A systematic review. J Gen Intern Med 2012; 27:861-7. https://doi.org/10.1007/s11606-011-1952-x.

40. Lin OS, Keeffe EB, Sanders GD, Owens DK. Cost-effectiveness of screening for hepatocellular carcinoma in patients with cirrhosis due to chronic hepatitis C. Aliment Pharmacol Ther 2004; 19:1159-72. https://doi.org/10.1111/j.1365-2036.2004.01963.x.

41. Trevisani F, D'Intino PE, Morselli-Labate AM, Mazzella G, Accogli E, Caraceni P, et al. Serum alpha-fetoprotein for diagnosis of hepatocellular carcinoma in patients with chronic liver disease: Influence of $\mathrm{HBsAg}$ and anti-HCV status. J Hepatol 2001; 34:570-5. https://doi.org/10.1016/s0168-8278 (00)00053-2

42. Sherman M. Alphafetoprotein: An obituary. J Hepatol 2001; 34:603-5. https://doi.org/10.1016/s0168-8278(01)00025-3.

43. Adachi Y, Tsuchihashi J, Shiraishi N, Yasuda K, Etoh T, Kitano S. AFP-producing gastric carcinoma: Multivariate analysis of prognostic factors in 270 patients. Oncology 2003; 65:95-101. https://doi.org/10.1159/000072332.

44. Sato Y, Sekine T, Ohwada S. Alpha-fetoprotein-producing rectal cancer: Calculated tumor marker doubling time. J Surg Oncol 1994; 55:265-8. https://doi.org/10.1002/jso.2930550414.

45. Tangkijvanich P, Anukulkarnkusol N, Suwangool P, Lertmaharit S, Hanvivatvong $\mathrm{O}$, Kullavanijaya $\mathrm{P}$, et al. Clinical characteristics and prognosis of hepatocellular carcinoma: Analysis based on serum alpha-fetoprotein levels. J Clin Gastroenterol 2000; 31:302-8. https://doi.org/10.1097/00004836-200012000-00007.

46. Bolondi L. Screening for hepatocellular carcinoma in cirrhosis. J Hepatol 2003; 39:1076-84. https://doi.org/10.1016/s01688278(03)00349-0.

47. Singal A, Volk ML, Waljee A, et al. Meta-analysis: surveillance with ultrasound for early-stage hepatocellular carcinoma in patients with cirrhosis. Aliment Pharmacol Ther 2009; 30:37-47. https://doi.org/10.1111/j.1365-2036.2009.04014.x.

48. EASL Clinical Practice Guidelines: Management of hepatocellular carcinoma. J Hepatol 2018; 69:182-236. https://doi. org/10.1016/j.jhep.2018.03.019.

49. Llovet JM, Fuster J, Bruix J; Barcelona-Clínic Liver Cancer Group. The Barcelona approach: Diagnosis, staging, and treatment of hepatocellular carcinoma. Liver Transpl 2004; 10:S115-20. https://doi.org/10.1002/lt.20034. 